\title{
Pengembangan instrumen asesmen pemahaman konseptual pada materi zat aditif dan zat adiktif serta akibatnya terhadap kesehatan
}

\author{
Anisyah Fadhillah, Sugiyanto, Muhammad Fajar Marsuki \\ Universitas Negeri Malang, Jl. Semarang No. 5 Malang, Jawa Timur, Indonesia \\ *Penulis korespondensi, Surel: sugiyanto.fmipa@um.ac.id
}

Paper received: 01-03-2021; revised: 15-03-2021; accepted: 31-03-2021

\begin{abstract}
Abstrak
Penelitian Pengembangan ini memiliki tujuan untuk instrumen asesmen pemahaman konseptual dapat memonitori jawaban tebakkan siswa. instrumen asesmen pemahaman konseptual pada materi zat aditif dan zat adiktif serta akibatnya terhadap kesehatan yang terdapat di sekolah berdasarkan analisis produk masih pada bentuk soal pilihan ganda karena termasuk tes objektif oleh sebab itu tes objektif mempunyai beberapa kelemahan seperti siswa yang memiliki kemampuan bernalar tidak dapat dilihat, akan mendapat keuntungan siswa yang menduga jawaban sehingga siswa oleh jawaban tebakkan tersebut tidak dapat memantau pemahaman secara utuh. Oleh sebab itu, dibutuhkan butir soal pada aspek yang diukur adalah sama tetapi jenis susunannya beda, di mana jenis bentuk soal ini dapat memantau jawaban tebakkan dari siswa. Penelitian ini menggunakan angket yang disebarkan kepada sepuluh orang siswa dan kepada tiga orang guru. Menggunakan metode kajian literatur dan penyebaran angket yang bertuju pada siswa dan guru dalam instrumen penilaian pemahaman konseptual pada materi zat aditif dan adiktif serta akibatnya terhadap kesehatan. Berdasarkan kajian literatur dilakukan penelitian pengembangan, maka diperoleh solusi yang ideal dalam pemecahan masalah dengan pengendalian jenis butir soal berdasarkan aspek yang diukur sama tetapi jenis susunannya berbeda, yaitu dengan jenis soal selected respons item dan constructed respon item.
\end{abstract}

Kata kunci: Instrumen Penilaian; Pemahaman Konseptual; IPA.

\section{Pendahuluan}

Kurikulum 2013 mempunyai tujuan untuk meningkatkan mutu pendidikan, proses pendidikan dan hasil pendidikan. Usaha untuk meningkatkan suatu mutu pendidikan, pemerintah menerbitkan berbagai peraturan baru terkait kebijakan kurikulum 2013 yaitu standar nasional pendidikan. Terdapat 5 standar pendidikan nasional yaitu: standar kemampuan lulusan, standar proses, standar isi, standar penilaian pendidikan, dan standar pendidik dan kegiatan kependidikan.

Standar penilaian pendidikan merupakan kriteria terkait prosedur, mekanisme, dan hasil belajar siswa berdasar instrumen penilaian (Permendikbud No. 32 Tahun 2013). Setiap kurikulum mempunyai paradigma dan karakteristik yang berbeda. Hal tersebut erat dengan kondisi dan kebutuhan di masa depan, termasuk cara dan sistem penilaian yang dilakukan.

Menurut Permendikbud Nomor 81A Tahun 2013, pengertian penilaian sama dengan asesmen. Penilaian merupakan pemberitahuan proses mengumpulkan dan mengelola untuk hasil belajar siswa terukur ketercapaiannya (Permendikbud Nomor 23 Tahun 2016). Asesmen adalah proses pembelajaran yang penting karena dapat menentukan tingkat keberhasilan proses pembelajaran pada siswa. Standar pendidikan kurikulum penilaian 2013 merujuk pada Permendikbud No. 66 tahun 2013 tentang standar pendidikan penilaian dengan kriterium bersangkut prosedur, mekanisme, dan hasil belajar siswa dari instrumen penilaian. Penilaian hasil belajar siswa meliputi kompetensi sikap, pengetahuan, dan 
keterampilan secara seimbang yang dilakukan dapat digunakan untuk menentukan setiap siswa posisi relatif terhadap standar yang sudah ditetapkan.

Menurut Permendikbud Nomor 66 Tahun 2013, instrumen asesmen hendaknya disatukan, ekonomis, jelas, objektif, dapat dipertanggungjawabkan, dan edukatif terhadap hasil belajar siswa. Pendidik menilai kompetensi sikap yang dilakukan penilaian diri melalui observasi, teman sejawat menilai, dan jurnal. sekalipun pengetahuan kompetensi, pendidik menempuh penilaian berupa tes tulis, tes lisan dan penugasan. Kompetensi keterampilan dinilai melangkaui penilaian kinerja. Berdasarkan hasil wawancara dan hasil analisis produk instrumen asesmen dari beberapa sekolah di Kota Malang yaitu antara lain SMP LAB UM, SMP Smart School Brawijaya dan SMPN 2 Pakisaji. Instrumen asesmennya rata-rata dalam bentuk soal pilihan ganda dan siswa rentan menerka-nerka jawaban. Oleh sebab itu, Instrumen asesmen yang dibuat dapat mengukur pemahaman konseptual siswa secara utuh, mampu memantau jawaban tebakkan pada siswa, dengan ditampilkan ragam bentuk soal yaitu, meliputi jenis soal benar - salah, pilihan tunggal (pilihan ganda), hubungan antar hal dan jawaban singkat. Berdasarkan bentuk soal tersebut jawaban siswa bisa dipantau, sehingga untuk dipantau jawaban siswa bukan dari hasil menebak, dilakukan pengendalian berdasarkan jenis butir soal yang dikembangkan, dan dibutuhkan butir soal dengan aspek yang diukur adalah sama tetapi beda jenis susunannya, di mana dari bentuk soal itu dapat dipantau jawaban tebakkan dari siswa. Instrumen asesmen yang dikembangkan juga dapat terukur dan valid.

Berdasarkan permasalahan di atas maka dilakukan studi literatur terkait instrumen pemahaman konseptual untuk dijadikan solusi dalam memantau jawaban tebakkan dari siswa. Penelitian ini mencoba mengembangkan instrumen asesmen dengan ragam soal selected response items dan constructed response items.

Berdasarkan Permendikbud Nomor 24 Tahun 2016, Kompetensi Inti (KI) yaitu tingkat kesanggupan oleh siswa yang harus dimiliki untuk standar lulusan kompetensi yang dicapai. Kompetensi inti meliputi kompetensi perilaku sosial, pengetahuan, perilaku spiritual, dan keterampilan. Kompetensi Dasar adalah materi yang harus ada dan dicapai minimal pembelajaran oleh kemampuan siswa. Dalam KD 3.6 siswa dituntut paham berbagai minuman dan makanan dalam zat adiktif, zat aditif, serta penyebabnya terhadap kesehatan. Zat adiktif dan Zat aditif merupakan materi dalam ilmu IPA agar memahami konsep yang menuntut siswa. Oleh karena itu, penting melakukan instrumen asesmen pengembangan yang menilai pemahaman konseptual siswa secara konkret terkait materi tersebut. Hal inilah yang mendorong peneliti untuk mengembangkan instrumen asesmen pemahaman konseptual pada materi zat aditif dan zat adiktif serta akibatnya terhadap kesehatan.

\section{Metode}

Metode penelitian ini ialah wawancara, analisis produk instrumen asesmen, dan kajian literatur tentang instrumen asesmen pemahaman konseptual pada materi berbagai minuman dan makanan zat aditif, zat adiktif serta akibatnya terhadap kesehatan, yang dapat dijadikan solusi untuk memantau jawaban tebakkan dari siswa. Instrumen penelitian ini menggunakan penyebaran angket kepraktisan terkait produk yang sudah dikembangkan kepada 3 guru IPA dan 10 orang siswa SMP yang telah mempelajari materi zat aditif dan zat adiktif serta akibatnya terhadap kesehatan. 


\section{Hasil dan Pembahasan}

Hasil analisis dari wawancara, mengkaji literatur terkait penilaian pada Kurikulum 2013 dan menganalisis produk soal yang terdapat pada empat sekolah di Kota Malang antara lain, SMP Laboratorium UM, SMP Brawijaya Smart School, SMP Negeri 3 Singosari dan SMP Negeri 2 Pakisaji, diperoleh hasil berikut:

Penilaian yang dilakukan oleh guru terhadap siswa berupa tes objektif dengan menggunakan jenis soal pilihan tunggal untuk memantau pemahaman konseptual siswa.

Menggunakan instrumen untuk menilai pemahaman konseptual materi zat aditif dan zat adiktif serta akibatnya terhadap kesehatan siswa pada penelitian-penelitian terkait peningkatan hasil belajar IPA dan identifikasi pemahaman konseptual berupa tes objektif dengan jenis soal pilihan tunggal.

Berdasarkan data tersebut, penilaian seharusnya penilaian yang harus dinilai secara tepat dan efisien. Jenis soal yang digunakan masih memungkinkan siswa untuk menerkanerka jawaban, sehingga tidak dapat menilai pemahaman konseptual siswa secara konkret. Oleh sebab itu, instrumen asesmen pemahaman konseptual pada materi zat aditif dan zat adiktif serta akibatnya terhadap kesehatan perlu dikembangkan. Dengan demikian, pemahaman siswa terkait materi IPA (zat aditif dan zat adiktif serta akibatnya bagi kesehatan) dapat terukur dengan baik.

Penelitian sebelumnya, Instrumen yang digunakan untuk menilai pemahaman konseptual siswa pada penelitian peningkatan hasil belajar kimia dan identifikasi pemahaman konseptual berupa tes objektif dengan jenis soal pilihan tunggal seperti yang dilakukan oleh Ramadhani (2010), Rahmawati (2011), dan Aprilia (2016). Menurut Dimiyati dan Mudjiono dalam Sulalah (2017), instrumen tes objektif punya beberapa kelemahan di antaranya kemampuan bernalar siswa terhadap instrumen tes objektif tidak dapat dilihat, siswa yang menerka-nerka jawaban mendapatkan keuntungan, penafsiran soal sukar sehingga memungkinkan kebocoran. Tidak dipungkiri bahwa jenis soal sukar dan memungkinkan adanya jawaban menebak (guessing) dari siswa. siswa oleh jawaban menebak tersebut tidak dapat memantau pemahaman secara utuh siswa.

Oleh karena itu, untuk memantau siswa dari jawaban bukan hasil guessing, maka melakukan pengendaliannya berdasar jenis butir soal yang dikembangkan, oleh sebab itu, dibutuhkan butir soal pada aspek yang diukur adalah sama tetapi jenis susunannya beda, di mana jenis bentuk soal ini dapat memantau jawaban tebakkan dari siswa. penelitian ini mencoba melakukan pengembangan instrumen asesmen dengan ragam soal selected response item dan constructed response item.

Penilaian hasil belajar siswa dapat dilakukan menggunakan instrumen. Instrumen asesmen pemahaman konsep pada materi zat aditif dan zat adiktif yang dikembangkan berupa tes kertas dan pena (paper and pencil test). Airasian, dkk (2007) membagi instrumen asesmen yang berupa paper and pencil test menjadi dua jenis soal, yaitu selected response items (soal objektif) dan constructed response items (soal subjektif). 
Jenis soal selected response item ini membutuhkan siswa untuk memilih jawaban benar dari beberapa alternatif jawaban. Secara umum, yang termasuk selected response items adalah jenis soal benar - salah (true-false) dan pilihan ganda (multiple choice). Jenis soal pilihan ganda dikembangkan menjadi soal pilihan tunggal (memilih satu jawaban benar) dan hubungan antar hal (memilih jawaban benar berdasarkan hubungan sebab akibat), sedangkan yang termasuk dalam constructed response item salah satunya adalah jawaban singkat (short answer).

Hasil data kuantitatif angket kepraktisan pengguna guru instrumen asesmen pemahaman konseptual pada materi zat aditif dan zat adiktif dinyatakan sangat valid dengan rentang $98,61 \%$ dan siswa data kuantitatif angket kepraktisan pengguna instrumen asesmen pemahaman konseptual pada materi zat aditif dan zat adiktif serta akibatnya terhadap kesehatan dinyatakan sangat valid dengan rentang 95,55\%. Hasil data kualitatif ditunjukkan pada tabel 1 berikut:

Tabel 1. Saran dan Masukkan Pengisian Angket Kepraktisan Pengguna oleh Guru dan Siswa

\begin{tabular}{|c|c|}
\hline Guru & Saran dan Masukkan \\
\hline Guru 1 & - \\
\hline Guru 2 & Soal sudah sesuai \\
\hline Guru 3 & $\begin{array}{l}\text { Soal yang dibuat sudah sangat baik dan jelas sehingga dapat dipakai untuk } \\
\text { mengukur pemahaman siswa. Hanya perlu memperhatikan aturan penulisan } \\
\text { saja, tidak menggunakan kata hubung di awal kalimat. } \\
\text { Selain baik untuk mengukur tingkat pemahaman siswa, soal-soal yang } \\
\text { dituliskan baik dipakai untuk mengukur kemampuan literasi siswa. }\end{array}$ \\
\hline Siswa & Saran dan Masukkan \\
\hline Siswa 1 & - \\
\hline Siswa 2 & - \\
\hline Siswa 3 & - \\
\hline Siswa 4 & - \\
\hline Siswa 5 & - \\
\hline Siswa 6 & $\begin{array}{l}\text { Soal tentang zat adiktif dan zat aditif sangat mudah sekali karena ada } \\
\text { materinya juga }\end{array}$ \\
\hline Siswa 7 & Soal-soalnya sangat bermanfaat untuk dipelajari \\
\hline Siswa 8 & - \\
\hline Siswa 9 & - \\
\hline Siswa 10 & $\begin{array}{l}\text { Saya agak nggak terlalu paham materi ini bu maaf yah kalau saya isinya ada } \\
\text { yang salah }\end{array}$ \\
\hline
\end{tabular}

\section{Simpulan}

\subsection{Kesimpulan}

Berdasarkan permasalahan di atas untuk memantau jawaban tebakkan dari siswa diperlukan instrumen asesmen pemahaman konseptual pada materi zat aditif dan zat adiktif serta akibatnya terhadap kesehatan berdasar pada bentuk butir soal pada aspek yang diukur adalah sama tetapi beda jenis susunannya yaitu, dengan ragam soal selected response item dan constructed response item.

\subsection{Saran}

Instrumen asesmen ini dapat dikembangkan lebih lanjut berdasarkan pada KD yang diturunkan dari kompetensi inti pada aspek keterampilan. 


\section{Daftar Rujukan}

Airasian, P., Engemann, J., \& Gallagher, T. (2007). Classroom assessment: Concepts and applications (Canadian ed.). Toronto, ON, Canada: McGraw Hill.

Aprillia, E. (2016). Pengaruh model Think Talk Write (TTW) terhadap hasil belajar siswa kelas XI SMA Negeri 02 Batu pada materi Kelarutan dan Hasil Kali Kelarutan (Doctoral dissertation, Universitas Negeri Malang).

dan Kebudayaan, K. P. (2016). Permendikbud No 23 Tahun 2016 Tentang Standar Penilaian Pendidikan

dan Kebudayaan, K. P. (2016). Permendikbud No 24 Tahun 2016 Tentang Kompetensi Inti dan Kompetensi Dasar Pelajaran Pada Kurikulum 2013.

dan Kebudayaan, K. P. (2013). Permendikbud RI No. 66 Tahun 2013 tentang standar penilaian pendidikan. Jakarta: Kemendikbud.

Kemendikbud, R. I. (2013). Peraturan Pemerintah No. 32 Tahun 2013 tentang Perubahan atas Peraturan Pemerintah Nomor 19 Tahun 2005 tentang Standar Nasional Pendidikan. Jakarta: $t p$.

No, P. (2013). 81A Tahun 2013 tentang implementasi kurikulum. Jakarta: Depdiknas.

Rahmawati, D. S. (2011). Pengaruh penerapan model pembelajaran learning cycle terhadap hasil belajar dan retensi hasil belajar siswa kelas X SMA Negeri 9 Malang pada materi minyak bumi (Doctoral dissertation, Universitas Negeri Malang).

Rizqi, L. (2010). Pengaruh penerapan metode inkuiri terbimbing (guided inquiry) terhadap hasil belajar dan kemampuan berpikir tingkat tinggi siswa kelas XI IPA MAN 3 Malang pada materi kelarutan dan hasil kali kelarutan (Doctoral dissertation, Universitas Negeri Malang).

Sulalah, W. A., Suryadharma, I. B., \& Sukarianingsih, D. (2017). Analisis Kesulitan Peserta Remidi dalam Memahami Konsep Reaksi Redoks. J-PEK (Jurnal Pembelajaran Kimia), 2(1), 14-20. 